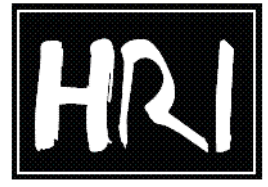

THE HUMAN RIGHTS INSTITUTE

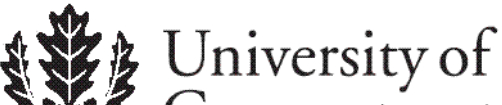

4 Connecticut

Economic Rights Working Paper Series

\title{
Human Rights and Public Opinion: From Attitudes to Action
}

Shareen Hertel

University of Connecticut

Lyle Scruggs

University of Connecticut

C. Patrick Heidkamp

Southern Connecticut State University

Working Paper 3

July 2007

The Human Rights Institute University of Connecticut Thomas J. Dodd Research Center 405 Babbidge Road, U-1205 Storrs, CT, 06269, USA

Email: humanrights@uconn.edu

Tel: 860-486-8739

Fax: 860-486-6332

http://www.humanrights.uconn.edu/ 


\begin{abstract}
How does the American public understand basic human rights issues - and what, if anything, are they willing to do to promote such rights? This article analyzes data from a 2006 national public opinion survey on human rights conducted by the authors. We explore how the American public understands three basic human rights that have not previously been included together in a single survey: the right not to be tortured, the right to freedom of thought and expression, and the right to a minimum guaranteed standard of living. We then assess respondents' willingness to promote, through their personal actions, the right to a guaranteed minimum standard of living - specifically, by purchasing "sweat-free" and/or "fair trade" products. We find public acceptance of a broad range of rights as inviolable human rights, and a strong association between willingness to pay more for both types of ethical consumption.
\end{abstract}

Keywords: : human rights, public opinion, sweatshops, fair trade

The authors gratefully acknowledge the research support of Rachel Jackson and the assistance of staff of the University of Connecticut Center for Survey Research and Analysis as well as the Roper Center for Public Opinion Research. We have also benefited from the comments on earlier drafts of this article from members of the University of Connecticut Economic Rights Reading Group/Human Rights Institute.

The Economic Rights Working Paper Series of the University of Connecticut Human Rights Institute is an effort to gather the most recent work on Economic Rights. This paper is work in progress. The authors remain copyright holders of this paper.

This working paper is indexed on RePEc, http://repec.org/ 
Overview. Since the founding of the modern human rights regime in the wake of World War II, public policy has taken place in the name of human rights -- both at the international and the domestic levels. The foreign policy arena has historically been the battleground in the struggle over rights -- particularly during the Cold War era, when efforts to promote capitalism or communism were marked by bitter rhetoric over the denial of human rights of different types in the Soviet Union, the United States, and their proxies. With the end of the Cold War and the advent of an intensified wave of contemporary globalization, human rights debates have shifted, moving from the fulcrum of a bipolar standoff to the nexus of a wide-ranging and often cross-cutting series of foreign policy and domestic policy debates. These include debates over transitional justice, economic rights in the context of neoliberal economic integration, and, most recently, civil and political rights in the context of the global "war on terrorism."

But how do US citizens understand the human rights which are the focus of policies made in their name? And what actions will they take (or not) when motivated by such beliefs? Political scientists and human rights scholars from varying disciplines have analyzed the origins of rights, their evolution (as dependent variable) and impact (as independent variable) on policy outcomes at varying levels. But there is a surprising lack of analysis of American or international public opinion as it relates to both the meaning and practice of human rights. Few survey questions ask whether respondents actually believe that certain rights widely enshrined in international law are, in fact, rights and if so, whether these rights are inviolable or conditional. Fewer still simultaneously ask about beliefs in rights and corresponding personal behaviors.

This article takes public opinion on human rights seriously for several reasons. We argue that if citizens elect leaders to represent their interests - including their interests in human rights protection and promotion, abroad and at home - then central to analyzing the quality of democracy is the task of analyzing what citizens "think" rights are and assessing how fully that understanding is mirrored (or not) in public policy formulation and outcomes. Nongovernmental actors also play a key role in defining the quality of democracy: they can promote enhanced responsiveness of government and other powerful nongovernmental actors (e.g., social and corporate leaders) to public demands for human rights protection and promotion, or they can thwart such responsiveness (Andreopoulos, Arat, and Juviler 2006; Bob 2005). More comprehensive information on what the public does - and does not - understand about rights can fuel new and innovative citizen-led, market-led, and government-led strategies for protecting and promoting a fuller scope of rights more effectively.

This article aims to help fill the gap in literature on human rights and public opinion by analyzing new data from a 2006 national (US) survey on human rights conducted by the authors. Our survey explored not only the public's understanding of three basic human rights but also respondents' willingness to promote one particular type of right namely, the economic right to a guaranteed minimum standard of living - by purchasing 
"sweatshop-free" and/or "fair trade" products. ${ }^{1}$ It is unique for drawing together questions on a range of human rights (i.e., civil, political and economic) while simultaneously addressing the issue of related behavior (in this case, ethical consumption). Among our key findings were some surprising ones regarding public acceptance of a broad range of rights. For example, support for the set of civil and political rights that have defined political liberalism for centuries is higher in the American population (over 70\%) than support for economic rights (64.5\%). Nevertheless, $80 \%$ of those who support civil and political rights also support a guaranteed minimum standard of living.

Interesting distinctions among Americans emerge from the polling results. Income differences play no significant role in differentiating support for the human right to protection from torture, or support for a human right to a minimum living standard. Minorities and women, however, are more likely to support an unconditional human right against torture than are other people. We find an opposite pattern emerges with respect to support for the right to freedom of thought and expression. For this more conventional human right, we find that traditionally more powerful social groups (e.g., whites and males) voice stronger support.

We explored consumer willingness to pay for products in an import-competing sector (i.e., apparel) and a non-import competing sector (i.e., coffee) and found a solid majority of Americans are willing to pay more for ethically produced goods. About $68 \%$ are willing to pay more for a $\$ 20$ "sweat-free" sweater. (Those with less education are considerably more willing to pay more, as are those with higher incomes. Interestingly, non-whites, despite their high support for the human right to a minimum standard of living in principle, are less likely to pay more for a "sweat-free" sweater.) Over $75 \%$ of those who regularly buy coffee in the grocery store report a willingness to pay at least 50 cents more per pound for "fair trade" coffee, and over half of regular coffee buyers surveyed report that they are willing to pay more than one dollar per pound more. Willingness to pay for one product is associated with about a 10-fold increase in the chance that respondents would pay the premium for the other.

Literature review. There is a vast scholarly literature on human rights, spanning multiple disciplines, though work in international law (Henkin, Neuman, Orentlicher, and Leebron 1999; Steiner and Alston 2000; Claude 1976) and international relations (Donnelly 2007; Forsythe 2006; Keck and Sikkink 1998; Risse, Ropp and Sikkink; Bob 2005) predominates. Comparative politics scholarship on human rights includes work by academics such as Landman (2002; 2005), Arat (2001), Cingranelli and Richards (2003) as well as work by comparatively oriented practitioners such as Hayner (2001) on truth commissioners or Farmer (2005) on the right to health, for example.

\footnotetext{
${ }^{1}$ The term "sweatshop" has traditionally been associated with the poor workplace conditions of individual firms (Ross 2004; Liubicic 1998; Rodríguez-Garavito 2005). "Fair trade" encompasses a broader set of requirements related to mode of production and market prices for given commodities or goods (Levi and Linton 2003; Loureiro and Lotade 2005) such as coffee, cocoa, or handicraft items. "Fair trade" may include both labor and environmental criteria (Roberts 1995), such as organic production of foodstuffs.
} 
Yet little work in the human rights field engages the question of public opinion on human rights. There are a handful of scholarly articles on the subject produced over the past two decades. But in general, they do not cover a broad a range of rights. Nor has most prior work explored respondents' foundational understandings of rights. DiazVeizades, Widaman, Little and Gibbs note the "surprising dearth of psychological research focusing specifically on human rights attitudes" (1995: 314). Nor has prior research linked such understandings to concrete expression in personal action, such as willingness to purchase ethically-produced goods.

Geyer and Shapiro (1988) analyzed national (US) public opinion polls conducted on human rights along with journalistic coverage of the issue from the mid 1970s through the late 1980s. They found that "defense of human rights in other countries has been a strikingly unimportant issue for the American public" (Geyer and Shapiro 1988: 386). Pritchard, in a 1991 reassessment of Geyer and Shapiro's findings, argued that this earlier work understated the public salience of the issue.

But the range of rights discussed by Geyer and Shapiro, as well as Pritchard, was narrowly civil and political - with no questions linked to social and economic rights. For example, previous surveys have focused on protection from political oppression or foreign policy intervention to prevent genocide, rather than the right to work or the right to education. The full spectrum of human rights - civil, political, economic, social and cultural - is enshrined in international law, but US surveys have typically focused only on half those rights. Moreover, the focus of human rights questions in previous polling was either on the instrumental use of rights in foreign policy or the level of rights violations domestically, but did not explore respondents' intrinsic understanding of rights or their personal actions as a consequence of such attitudes.

Some work on US attitudes about human rights relies on small, unrepresentative samples. ${ }^{2}$ Dennis Chong (1993) analyzed how "citizens think and reason about controversial political issues involving rights and liberties," including human rights, based on a survey of 30 randomly-selected San Francisco Bay area respondents. McFarland and Mathews (2005a; 2005b) analyzed the relationship between endorsement of human rights ideals and expressed commitment to human rights-related foreign policy, based on a survey of North American college students and faculty. ${ }^{3}$ Diaz-Veizades,

\footnotetext{
${ }^{2}$ Cross-nationally, Anderson, Regan and Ostergard (2002; 2005) analyzed public opinion in Eastern and Central Europe and found a significant relationship between individual evaluations of human rights conditions and overall levels of government repression -- i.e., a negative assessment of human rights in countries with higher levels of oppression (2002). Respondents with higher levels of education tended to be more critical of the rights situation in their own countries than those who were comparably less educated (2005). More recent work by Carlson and Listhaug (2007) expands the geographic scope to include over 50 countries in nearly all major world regions. But all of this work concentrates largely on civil and political rights. Nor does it link attitudes about rights to action, something that Carlson and Listhaug recently pointed out is a priority for research in this area (2007: 480).

${ }^{3}$ McFarland and Mathews administered their survey to 235 respondents, 161 non-student adults and 74 upper-division college students (2005: 375).
} 
Widaman, Little and Gibbs (1995) conducted two surveys also using a limited sample of college students and faculty in North America, ${ }^{4}$ and carried out factor analysis to determine the underlying structure of attitudes. Their questionnaire covered a range of rights specified in the Universal Declaration of Human Rights, the cornerstone of international human rights law -- including the "right to an adequate standard of living" (1995: 318) and the "right to freedom of opinion" (1995: 319), both of which are covered in our own 2006 national public opinion survey (see Appendix A for question wordings).

The Universal Declaration of Human Rights, however, includes an article on the right to be free from torture ${ }^{5}$-- and Diaz-Veizades et alia did not include this issue in their human rights questionnaire. Since 1990, there have been at least 29 public opinion polls conducted nationally in the United States that include questions on torture. ${ }^{6}$ Two-thirds of the polls (i.e., 21 of them) were conducted after April 2004, when the US public learned that American military personnel had tortured prisoners held at the Abu Ghraib detention facility in Iraq during the course of the current Iraq War. The questions included in these surveys are generally of two types. Some are instrumentally focused: they probe public attitudes about the use of torture as a means to an end - either foreign policy promotion, or protection of public security. Other questions attempt to engage respondents in assessing the actual prevalence of torture within the United States or abroad.

Yet none of these surveys has explored public attitudes about the nature of torture as a human rights issue by asking, for example, whether protection from torture itself should be considered a human right always, sometimes, or never. Nor do previous human rights surveys (on torture or broader topics such as freedom of expression) ${ }^{7}$ engage respondents in exploring how their beliefs on these rights issues might affect their own personal actions. And previous surveys on ethical consumption (such as those on child labor, antisweatshop purchasing, or fair trade) do not frame these issues in human rights terms. ${ }^{8}$ Our survey was designed with these considerations centrally in mind.

\footnotetext{
${ }^{4}$ Diaz-Viezades et alia conducted their two surveys, respectively, among 365 college students and among 212 college students and 42 adult faculty in North America (1995: 313).
}

5 Article 5, UDHR: "No one shall be subjected to torture or to cruel, inhuman or degrading treatment or punishment." Full text of this treaty is available from the webpage of the United Nations Office of the High Commissioner for Human Rights: www.ohchr.org

\footnotetext{
${ }^{6}$ See Appendix B for a full listing of polls conducted in the United States from 1990-2007 which include questions on torture. The authors obtained data from searches of the iPOLL Databank and other resources provided by the Roper Center for Public Opinion Research, University of Connecticut (accessed 19 June 2007 and 27 June 2007).

${ }^{7}$ See Appendix C for full listing of polls conducted in the United States from 1990-2007 which include questions on freedom of thought, expression and speech. The authors obtained data from searches of the iPOLL Databank and other resources provided by the Roper Center for Public Opinion Research, University of Connecticut (accessed 19 June 2007 and 27 June 2007)

${ }^{8}$ See Appendix D for a full listing of polls conducted in the United States from 1990-2007 which include questions on child labor, sweatshops, and/or fair trade. The authors obtained data from searches of the iPOLL Databank and other resources provided by the Roper Center for Public Opinion Research, University of Connecticut (accessed 19 June 2007 and 27 June 2007).
} 
Survey design and major findings. Our interest in human rights is broad-ranging, (hence the wide scope of questions included in the survey) but also focused around the challenge of interpreting the link (if any) between attitudes and action - hence, our focus on ethical consumption. In developing this project, we have also been particularly mindful of the lack of human rights survey work and analysis on economic rights. We thus combined questions on multiple issue areas within human rights (i.e., torture, freedom of thought/conscience, and economic rights) with questions on ethical consumption, ${ }^{9}$ and integrated them within a larger national public opinion survey conducted in November 2006 by the University of Connecticut Center for Survey Research and Analysis.

The survey design enabled us to explore the micro-foundations of human rights attitudes (e.g., mostly demographic characteristics of those with particular attitudes) while at the same time analyzing the links - if any - between attitudes and expressions in practice (i.e., questions about the propensity for ethical consumption). As noted above, we did find a link between attitudes about the right to a minimum standard of living and the respondent's expressed willingness to pay more for fair trade coffee, as discussed in greater detail below.

Differences in the mean responses to the aspects of human rights questions. Surprisingly few surveys of public attitudes ask directly about how people regard different aspects of human rights claims. We asked three different questions regarding three different areas of these types of claims; the prelude to the question was the following:

Now I'm going to read you some possible human rights. For each one please tell me whether YOU think it is a right that should be guaranteed to every human being and never violated, a right that may be desirable but that can be violated under certain circumstances, or not really a right at all. (For full question wordings, see Appendix A.)

Figure 1 displays the aggregate responses to each of these questions. ${ }^{10}$ As we anticipated, support for the set of civil and political rights that have defined political liberalism for centuries is higher in the American population than support for economic rights. Over $70 \%$ of Americans say freedom from torture and freedom of expression and

\footnotetext{
${ }^{9}$ Ethically produced goods are a small subset of overall products in sectors such as textiles and agriculture: De Pelsmacker, Driesen and Rayp report that "ethical labeling initiatives with respect to, for instance, organic food, products free from child labor, legally logged wood, and fair-trade products, often have market shares of less than 1\%" (2005: 364). Yet the market for such products is growing. Overall sales of fair trade commodities in North America and the Pacific Rim rose by close to 40\% in 2003 (Loureiro and Lotade 2005), totaling \$291.75 million -- with coffee representing 32\% of those sales (Fair Trade Federation 2005).

${ }^{10}$ In this and all other results, we have used sampling weights.
} 
thought are guaranteed rights to all people. A lower percentage (i.e., 64.5\%) of respondents consider a guaranteed minimum standard of living to be an inviolable human right, and about $12 \%$ of the population does not consider it a human right at all. Indeed, about twice as many people (4\% versus $2 \%$ ) had no clear opinion on this particular right versus the other two.

\section{INSERT FIGURE 1 HERE}

One apparent difference in attitudes about the right to free expression and about protection against torture is that more people say that protection from torture is "not really a right at all." Since almost identical numbers of people responded that both are guaranteed human rights (and have almost identical non-response rates), it is tempting to argue that these differences are due to the fact that torture has become much more legitimized since terrorist attacks of September 11, 2001, as reflected in our polling results from 2006. Methods (at least) bordering on torture have been used by the United States' government in its military operations in Iraq since 2003 and in the war on terrorism since at least that date. Public knowledge of these may have reduced popular opposition to its practice. Currently, however, we simply lack detailed comparative survey data to answer that question definitively.

The second notable result is that a substantial majority of Americans believe in basic economic rights, not only in a limited set of political and civil rights commonly associated with classical political liberalism. About $80 \%$ of those who support guaranteed civil and political rights also support a guaranteed minimum standard of living. Incidentally, this kind of basic support for the poor is not inconsistent with other public opinion surveys, such as the General Social Survey, which find that historically $65-70 \%$ of Americans support spending more on assistance to the poor. ${ }^{11}$

A final notable observation about these results is what they imply about the existence of widespread norms in favor of human rights. What pattern of support would cast doubt on normative support for human rights? Although all three of these issues are elements of de jure international human rights law, on a generous counting, less than a majority of Americans (46\%) answer that all three of these rights are inviolable, and fewer than two-thirds of Americans believe that any two are guaranteed while one other is conditional. ${ }^{12}$

On the other hand, a more optimistic rendering of these data would suggest widespread normative support for human rights. Only $18 \%$ of respondents hold that one or more of the three aspects of human rights is not really a right at all, leaving a vast majority who accept some, conditional support of human rights in principle. Almost $75 \%$

\footnotetext{
${ }^{11}$ Tom W. Smith, "Trends in National Spending Priorities, 1973-2006," General Social Survey, National Opinion Research Center, University of Chicago, 10 January 2007. Full report available electronically via: http://www-news.uchicago.edu/releases/07/070110.gss.shtml

${ }^{12}$ This counts those respondents who replied that the right is "guaranteed" to two of the three items, and replied "don't know" to the third.
} 
of the public believes that at least one of these freedoms is an inalienable human right. If the idea is that there is good level of support (if not complete consensus), one might want to investigate why human rights policies are often of limited scope.

In the context of a national social survey, we cannot shed much light on many of the explanations for national positions on human rights policy as a foreign policy priority. Factors such as commercial interests, sovereignty, and regional power dynamics all undoubtedly play a role in qualifying public support for human rights-oriented foreign policy. Our survey was primarily limited to demographic and basic political information on party identification and partisanship. From these areas we can shed some light on some questions, such as which groups in society are more likely to express support for human rights. Such an analysis can play an important role in democratic policy making and democratic political discourse.

One obvious argument is that support for a particular human right is correlated with general self-interest or "group" interest. For example, we might expect low-status racial or ethnic groups to be more supportive of absolute rights to protection from torture compared with majority groups. Similarly, those with lower market status -- those with low education, low income or in minority groups -- might be more likely to support a guaranteed living standard than those who are well-placed economically. In this section, we examine these possible differences in the social bases of support.

Table 1 shows support for freedom from mental and physical torture by race, gender, and income. The percentages show the proportion of respondents in each group supporting this as a fundamental human right. The last column shows the odds-ratio from a multivariate model predicting support for a fundamental right against torture. ${ }^{13}$

\section{INSERT TABLE 1 HERE}

These results indicate that being in politically more marginal groups does indeed increase support for a human right against torture: $70 \%$ of non-whites support an inviolable human right against torture, while only $62 \%$ of whites support such a right. In the multivariate model, non-whites are almost twice as likely to voice such support as are whites. Gender is an even more important factor separating support for a human right against torture in the United States: $78 \%$ of women, as opposed to $63 \%$ of men, support it. Controlling for other factors, women are more than twice as likely to support a fundamental right against torture. Income differences, by contrast, play no role in differentiating support for this human right. Support is almost identical for respondents in households with incomes above or below fifty thousand dollars a years. Looking at the effects of race and gender added together, about $83 \%$ of nonwhite females support

\footnotetext{
${ }^{13}$ The multivariate model controls for gender, income, race, education, party affiliation, age, adults in the household, and whether and not the respondent always looks for American-made products. Full results are available from the authors.
} 
freedom from torture as an unconditional right, while only just over half (56\%) of white males support freedom from torture as an unconditional right. ${ }^{14}$

Table 2 shows support for an inviolable right to a minimum standard of living. The table is structured in the same way as Table 1. As an additional indicator of poor income prospects, and thus a more self-interested basis for supporting such a right, we compare support among Americans with no formal education past high school and those with some post-secondary education.

\section{INSERT TABLE 2 HERE}

The results suggest that minority groups and those with limited human capital (proxied by education) are about twice as likely to support a human right to a minimum standard of living than whites or those with at least some education after high school. However, there is not very strong evidence that households with lower incomes are more likely to support a human right to a minimum living standard than are wealthier households. (The five point difference in overall response for each group is within the sampling margin of error in our survey.) ${ }^{15}$

Table 3 shows support for a fundamental human right to freedom of thought and expression. The only group difference that is clearly outside of the sampling margin of error is for gender, though difference between whites and non-whites are also large. What it most notable in the results for this variable is that more traditionally socially powerful groups tend to be more supportive of an unconditional right to freedom of thought and expression.

\section{INSERT TABLE 3 HERE}

Previous analysis of public opinion may help shed light on the nature of public support for basic civil liberties, such as freedom of thought and expression. Chong (1993) found that respondents "commonly answer questions about civil liberties" - such as freedom of thought and expression - "off the top of their heads" (1993: 871). In part, this is the result of public awareness of the Constitutional and statutory protections for such rights. Chong observes that legal norms are "probably the most important frame of reference used in public discussions of civil liberties, so we would expect that people would attempt to interpret these issues in such normative terms" (1993: 878).

Respondents answering civil liberties-related questions also consider which groups "are involved in the issue. The latter category includes personal references to how one's self

\footnotetext{
14 The corresponding predictions for the multivariate logit model are $88 \%$ of non-whites and females, and $60 \%$ of white males.

${ }^{15}$ We also tested for differences between households with incomes above and below \$25,000 and got similarly marginal results. One possible confounding factor that we could not control for in our survey is the number of earners in the household. A household with one earner reporting an income of $\$ 40,000$ could be expected to have quite different economic prospects than one composed of two earners making $\$ 20,000$ each.
} 
or one's own group is affected by the issue" (Chong 1993: 878). For example, white males, who in our survey expressed strongest support for an unconditional right to freedom of thought and expression, have historically had greatest say in defining such rights -- particularly in the context of early debates over "natural rights." This may explain the strong level of support for this type of right among this segment of the population surveyed.

When thinking about the structure of support within the American population for the entire international human rights regime (i.e., mapped across the three categories of rights covered in our survey), it is helpful to consider not only support for each of these rights individually but also support for all three of them jointly. All three are codified in international human rights law, which the United States has signed and, in many cases, ratified. $^{16}$

Table 4 shows support for the overall international human rights agenda broken down by gender, race, income, education, and partisan affiliation. Recall that less than half of people unconditionally support all three human rights items. The results in Table 4 suggest that only among Democrats and women does there appear to be majority support for international human rights law, and there it is only a bare majority.

\section{INSERT TABLE 4 HERE}

\section{Economic human right and public willingness to pay for ethically produced}

goods. One charge that might be leveled against these very general questions about support for human rights is that they lead to over-reporting of support. These questions require little commitment by respondents beyond expressing support for different types of rights. It is important to keep in mind that the questions were not phrased to inflate support. The questions state that support implies that the right be unconditional, and allows respondents to choose an "in-between" category that permits conditional violation of the right.

In one arena, our survey provides an opportunity to explore commitment to one type of human right-economic rights-in much greater depth to see if people's support for a minimum living standard in principle would be mirrored in practice. To do so, we asked respondents how much extra they would be willing to pay for two products, coffee and sweaters, if those products were produced under conditions that better provided for a minimum standard of living. The questions were not asked in ways that prompted respondents to refer back to their previous statements about human rights. The items chosen comprise one product (i.e., textiles) in an import competing sector, and another (i.e., coffee) that is not domestically produced.

\footnotetext{
${ }^{16}$ Particularly relevant for our discussion here, the US has signed and ratified both the Convention against Torture and Other Cruel, Inhuman or Degrading Treatment or Punishment, and the International Covenant on Civil and Political Rights. The United States has signed but not ratified the Covenant on Economic, Social and Cultural Rights.
} 
A popular conception of ethical consumption is that it has a limited potential market (concentrated among those with liberal political leanings and/or high disposable incomes). Our results, which are consistent with academic findings presented and reported elsewhere, suggest much broader public support. Overall, a solid majority of Americans are willing to pay more for ethically produced goods. Figures $\mathbf{2}$ and $\mathbf{3}$ show the distribution of responses for the willingness-to-pay for clothing and coffee, respectively. ${ }^{17}$

\section{INSERT FIGURES 2 AND 3 HERE (SIDE BY SIDE)}

Like three of the most widely reported polls on "anti-sweatshop" purchasing behavior - i.e., the Marymount (1995; 1996; 1999), University of Maryland/Program on International Policy Attitudes (2000) and Elliott and Richard (2001) polls -- we found that over two-thirds of our respondents would pay significantly more for a sweater made under good working conditions. ${ }^{18}$ About $68 \%$ are willing to pay something more for a $\$ 20$ "sweat-free" sweater. The vast majority of these people (62\% of Americans) report that they are willing to pay at least $\$ 5$ more, and more than one-third of Americans report that they would be willing to spend $\$ 10$ more.

\section{INSERT TABLE 5 HERE}

Table 5 provides the proportions of key demographic groups who say they are willing to pay a $\$ 5$ or more premium. Those with only a high school education were much more likely to be willing to pay a five dollar premium. Holding all other factors constant, the probability of being willing to pay $\$ 5$ or more falls from $75 \%$ to $58 \%$ if one has more than a high school degree. This is consistent with our earlier finding that those with more then secondary education are less likely to express support for an unconditional human right to a minimum standard of living. But other results diverge in important ways from those for support of the human right to a minimum living standard. Non-whites are less likely to pay more, and those with higher income are more willing to pay more. All of these results hold up in the multivariate analysis, implying that the lack of willingness to pay among non-whites is probably not a function of their systematically lower incomes.

Interestingly, while we might expect that those whose opinions on broader human rights questions would imply support for a sweat-free premium, there is little empirical

\footnotetext{
${ }^{17}$ Responses for sweaters were top-coded at $\$ 97$.

${ }^{18}$ In our poll, upwards of $75 \%$ of all respondents reported they would pay $\$ 2$ more for a $\$ 20$ sweater if it were produced without the use of sweatshop labor. Such a high rate of expressed support for ethical consumption mirrors the findings of the Marymount (1995; 1996; 1999), University of Maryland/PIPA (2000) and Elliott and Freeman (2001) polls - which found, respectively, that $85 \%$ of consumers surveyed by Marymount would pay $\$ 1$ more for a $\$ 20$ sweater consistently across the 1995,1996 , and 1999 polls; $75 \%$ of those surveyed by PIPA would pay $\$ 5$ more for a $\$ 20$ sweater; and that consumers surveyed for the Elliott and Freeman poll would pay $28 \%$ more on a $\$ 10$ item and $15 \%$ more on a $\$ 100$ item.
} 
support for this. The apparent differences across these groups in Table 5 are not statistically different from zero in either the bivariate or multivariate statistical analysis. On the other hand, there is some mixed evidence that those who support a guaranteed right to a minimum standard of living are willing to pay the $\$ 5$ or more premium. The eleven percentage point difference shown in Table 5 is marginally significant statistically $(\mathrm{p}<.07)$, but the effect is not statistically significant once we control for things like gender, income and education.

As with the sweat-free goods, a large majority of respondents in our survey reported a willingness to pay a premium for coffee produced according to standards more in line with assuring a minimum guaranteed standard of living. Coffee is the second most traded commodity in the world (after oil), and commands a significant price premium in the market. Suppliers of fair trade coffee in North America fetch an average premium of US\$0.62 (Ponte 2002). Recognizing the potentially transformative role of coffee production as a vehicle for economic development in poor countries, leading fair trade certification programs such as the Germany-based Fair Trade Organizations International have increasingly situated the concept of fair trade within the context of human rights. Our survey work explored this connection in greater detail.

We asked whether our respondents frequently purchased coffee, and, if so, whether or not they would be willing to pay more for coffee that was produced under a "Fair Trade" label, which ensures that producers are paid a minimum price for their coffee. We asked all regular coffee buyers how much more they would pay for it (i.e., the answers provided were nothing, 50 cents, \$1, \$2 and more than \$2). From 2001-5, the average retail price of coffee in the United States was \$3.01 (nominal, \$3.21 in December 2005 prices), so the choices are premiums of around 16\%, 33\% and 66\% (International Coffee Organization historical statistics, www.ico.org). As displayed in Figure 3, more than $75 \%$ of regular coffee buyers were willing to pay at least $\$ .50$ more for fair trade coffee, and more than half said they would pay a premium of $\$ 1$ or more. These figures are comparable to Loureiro and Lotade, who found that $73.18 \%$ of the consumers they interviewed in 2002 at five locations in Colorado and Wyoming were willing to pay a premium of at least 11 cents (over the original prices of $\$ 6.50$ per pound) for shade-grown coffee, which is frequently grown under fair trade conditions (2005: 131).

Table 6 produces the percentages willing to pay $\$ 1$ or more a pound among key demographic groups. Sampling errors are higher for this question, because we screened out people who do not regularly buy coffee, roughly halving the number of respondents. The results suggest that support for a guaranteed human right to a minimum standard of living is associated with a willingness to pay more for fair trade coffee. Holding other values at their mean, the predicted probability goes from $42 \%$ to $58 \%$ if one supports a guaranteed right to a minimum standard of living. (Notably, there is no relationship between supporting all three types of human rights and WTP for fair trade coffee.)

\section{INSERT TABLE 6 HERE}


Significantly, willingness to pay more for one of the two ethically-produced goods was highly correlated with willingness to pay more for the other in the multivariate model. Willingness to pay for one is associated with about a 10-fold increase in the chance that respondents would pay the premium for the other.

Conclusion. As noted at the outset, the literatures on public opinion and human rights rarely intersect. Our research offers new, national-level data on how the public understands a broad range of rights - and explores whether there is a connection between belief and expressed commitment to personal action in the form of "ethical consumption."

Such connections have more than scholarly relevance. We argue that democratic decision-making should reflect the values of citizens. Human rights preferences relate to values. Thus in order to accurately represent the public interest, policymakers need to understand what their constituents really think about human rights. For example, our survey results reveal that a higher proportion of people believe firmly in economic rights than is commonly assumed to be the case among Americans. Yet the United States is alone among industrialized nations in not having ratified the International Covenant on Economic, Social and Cultural Rights, and is the only nation other than Somalia not to have ratified the UN Convention on the Rights of the Child, a treaty with strong provisions on children's economic rights. The fate of domestic policy programs (such as "Headstart" or other US social welfare programs with strong implications for children's rights) is also rendered more insecure by the persistent disconnect in public policymaking and popular opinion on human rights (particularly with regard to economic rights).

Elected officials are not the only ones who can benefit from a deeper understanding of the relationship between public opinion and human rights. Advocacy organizations, too, stand to gain. Amnesty International, for example, has recently initiated a global campaign on economic rights (Goering 2006); more comprehensive polling data on related issues could enable Amnesty and like organizations to target their human rights education efforts more effectively. And organizations involved in promoting ethical consumption could better develop a market base armed with information on the demographics of support for key human rights issues as well as data on the depth of consumer willingness to pay for "sweat-free" or "fair-trade" products. This research is but a first step in forging deeper analytical and practical links between public opinion on human rights and popular action. 


\section{REFERENCES}

Anderson, Christopher, Patrick M. Regan, and Robert L. Ostergard. "Political Repression and Public Perceptions of Human Rights," Political Research Quarterly 55, 2 (June 2002): 439-456.

Anderson, Christopher, Aid Paskeviciute, Maria Sandovici, and Yuliya Tverdova. In the Eye of the Beholder? The Foundations of Subjective Human Rights Conditions in EastCentral Europe," Comparative Political Studies 38, 7 (2005): 771-798.

Andreopoulos, George, Zehra F. Kabasakal Arat, and Peter Juviler, editors. Non-State Actors in the Human Rights Universe. Brookfield, CT: Kumarian Press, Inc., 2006.

Arat, Zehra. Democracy and Human Rights in Developing Countries. Boulder, CO: Lynne Rienner Publishers, 2001.

Bob, Clifford. Marketing Rebellion: Insurgents, Media, and International Activism. Cambridge and New York: Cambridge University Press, 2005.

Carlson, Matthew and Ola Listhaug. "Citizens' Perceptions of Human Rights Practices: An Analysis of 55 Countries," Journal of Peace Research 44, 4 (2007): 465-483.

Chong, Dennis. "How People Think, Reason, and Feel about Rights and Liberties," American Journal of Political Science 37, 3 (August 1993): 867-899.

Cingranelli, David L. and David L. Richards, "Measuring the level, pattern and sequence of government respect for physical integrity rights," International Studies Quarterly 43, 2 (June 1999): 407-417.

Claude, Richard P. Comparative Human Rights. Baltimore, MD: Johns Hopkins University Press, 1976.

Diaz-Veizades, Jeannette, Keith F. Widaman, Todd D. Little, and Katherine W. Gibbs, “The Measurement of Human Rights Attitudes," The Journal of Social Psychology 135, 3 (1995): 313-328.

Dickson, Marsha A. "Utility of No Sweat Labels for Apparel Consumers: Profiling Label Users and Predicting Their Purchases," The Journal of Consumer Affairs 35, 1 (2001): 96-119.

Dickson, Marsha A. and Mary A. Littrell, "Consumers of Clothing from Alternative Trading Organizations: Societal Attitudes and Purchase Evaluative Criteria," Clothing and Textiles Research Journal 15 (1997): 20-33.

Dickson, Marsha A. and Mary A. Littrell, "Socially Responsible Behaviour: Values and Attitudes of the Alternative Trading Organisation Consumer," Journal of Fashion Marketing and Management 1 (October 1996): 50-69. 
Donnelly, Jack. International Human Rights, $3^{\text {rd }}$ edition. Boulder, CO: Westview Press, 2007.

Elliott, Kimberly Ann and Richard B. Freeman, "White Hats or Don Quixotes? Human Rights Vigilantes in the Global Economy," Working Paper 8102, National Bureau of Economic Research (January 2001).

Farmer, Paul. Pathologies of Power: Health, Human Rights and the New War on the Poor. Berkeley, CA: University of California Press, 2005.

Forsythe, David P. Human Rights in International Relations. Cambridge: Cambridge University Press, 2006.

Geyer, Anne E. and Robert Y. Shapiro, "A Report: Human Rights," The Public Opinion Quarterly 52, 3 (Autumn 1988): 386-398.

Goering, Curt. “Amnesty International and Economic, Social and Cultural Rights," in Ethics in Action: The Ethical Challenges of International Human Rights and Humanitarian Nongovernmental Organizations, Daniel A. Bell and Jean-Marc Coicaud, editors. Cambridge, UK: Cambridge University Press, 2006.

Hayner, Priscilla. Unspeakable Truths: Confronting State Terror and Atrocity. New York: Routledge, 2001.

Henkin, Louis, Gerald L. Neuman, Diane F. Orentlicher, and David W. Leebron. Human Rights. New York: Foundation Press, 1999.

Keck, Margaret and Sikkink, Kathryn. Activists Beyond Borders: Advocacy Networks in International Politics. Ithaca, NY: Cornell University Press, 1998.

Landman, Todd. "Comparative Politics and Human Rights," Human Rights Quarterly 24 (2002): 890-923.

Landman, Todd. Protecting Human Rights: A Comparative Study. Washington, DC: Georgetown University Press, 2005.

Levi, Margaret and April Linton, "Fair Trade: A Cup at a Time," Politics and Society 31, 3 (September 2003): 407-432.

Liubicic, Robert J. "Corporate Codes of Conduct and Product Labeling Schemes: The Limits and Possibilities of Promoting International Labor Rights Through Private Initiatives," Law and International Business 30, 1 (Fall 1998): 112-158.

Loureiro, Maria L. and Justus Lotade. "Do fair trade and eco-labels in coffee wake up the consumer conscience?” Ecological Economics 53 (2005): 129-138. 
Marymount University. The Consumers and Sweatshops (Arlington, VA: Marymount University Center for Ethical Concerns, November 1999). Available online at: www.marymount.edu/news/garmentstudy/overview.html

Marymount University. Garment Workers Study, report available from Marymount University Center for Ethical Concerns (Arlington, VA: Marymount, 1996).

Marymount University. Garment Workers Study, report available from Marymount University Center for Ethical Concerns (Arlington, VA: Marymount, 1995).

McFarland, Sam and Melissa Mathews, "Who Cares About Human Rights?" Political Psychology 26, 3 (2005): 365-385.

McFarland, Sam and Melissa Mathews, "Do Americans Care About Human Rights?" Journal of Human Rights 4, 3 (2005): 305-319.

Ponte, Stefano. Standards, Trade and Equity: Lessons from the Specialty Coffee Industry. Centre for Development Research Working Paper 02.12. Copenhagen, Denmark: Centre for Development Research, 2002.

Pritchard, Kathleen. "Human Rights: A Decent Respect for Public Opinion?" Human Rights Quarterly 13, 1 (1991): 123-142.

Risse, Thomas, Stephen C. Ropp, and Kathryn Sikkink. The Power of Human Rights: International norms and domestic change. New York: Cambridge University Press, 1999.

Roberts, James A. "Profiling Levels of Socially Responsible Consumer Behavior: A Cluster Analytic Approach and Its Implications for Marketing," Journal of Marketing 3 (Fall 1995): 97-117.

Rodríguez-Garavito, César A. "Global Governance and Labor Rights: Codes of Conduct and Anti-Sweatshop Struggles in Global Apparel Factories in Mexico and Guatemala," Politics and Society 33, 2 (June 2005): 203-233.

Ross, Robert J.S. Slaves to Fashion: Poverty and Abuse in the New Sweatshops. Ann Arbor, MI: University of Michigan Press, 2004.

Smith, Tom W. 'Trends in National Spending Priorities, 1973-2006," General Social Survey, National Opinion Research Center, University of Chicago, 10 January 2007. Full report available electronically via: http://wwwnews.uchicago.edu/releases/07/070110.gss.shtml

Steiner, Henry J. and Philip Alston. International Human Rights in Context: Law, Politics, Morals. Oxford: Oxford University Press, 2000, $2^{\text {nd }}$ edition. 


\section{APPENDIX A \\ Questions from the 2006 National Public Opinion Survey \\ Administered by the University of Connecticut \\ Center for Survey Research and Analysis \\ for Hertel, Scruggs and Heidkamp}

61:

QLS1 (I)

2006/11/27 20:42

QLS1. On a different topic, some clothing producers in foreign countries make their employees work in unsafe conditions, often called sweat shops, to keep costs and prices low. Would you be willing to pay more for clothing that you knew was made under SAFE working conditions, and not in sweat-shops?

Yes ......01

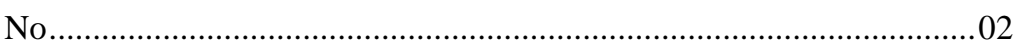

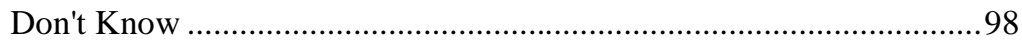

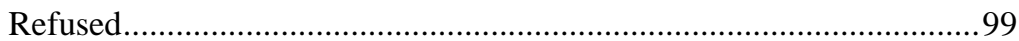

$\Rightarrow$ IQLS2

$\Rightarrow$ IQLS2

«QLS1»

$\Rightarrow$ IQLS2

62:

QLS1A (I)

2006/11/27 20:42

QLS1A. If you were considering buying a sweater priced around twenty dollars, how many MORE dollars would you be willing to pay for the sweater to get a guarantee that it was made under safe working conditions? (ENTER 2 DIGIT DOLLAR AMOUNT 0-96) (IF MORE THAN \$20, PROBE: Is that how much you would pay total or how much MORE you would pay?) (IF TOTAL: CODE THE DIFFERENCE BETWEEN THE ANSWER AND TWENTY DOLLARS.) \$E 096

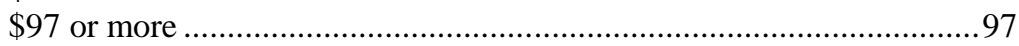

Don't Know ................................................................................ 98

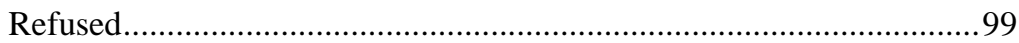

«LS1A »

63:

IQLS2 (I)

2006/11/27 20:42

IQLS2. Now I'm going to read you some possible human rights. For each one please tell me whether YOU think it is a right that should be guaranteed to every human being and never violated, a right that may be desirable but that can be violated under certain circumstances, or not really a right at all.

Continue. $01 \mathrm{D}$

«QLS2 »

64:

QLS2A (I)

$2006 / 11 / 2720: 42$ 
QLS2A. Freedom from physical and mental torture? (PROBE: Is that a right that should be guaranteed to everyone and never violated, a right that can be violated under certain circumstances, or not really a right at all?)

Guaranteed and never violated ............................................................... 01

Can be violated under some circumstances..............................................02

Not really a right at all....................................................................... 03

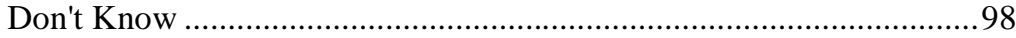

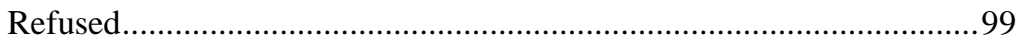

«LS2A »

\section{5:}

QLS2B (I)

2006/11/27 20:42

QLS2B. A guaranteed minimum standard of living? (PROBE: Is that a right that should be guaranteed to everyone and never violated, a right that can be violated under certain circumstances, or not really a right at all?)

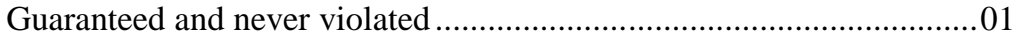

Can be violated under some circumstances ......................................... 02

Not really a right at all............................................................... 03

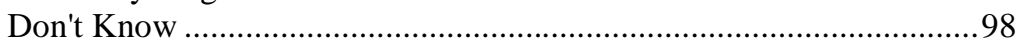

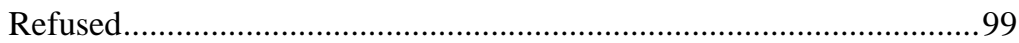

«QLS2B »

66:

QLS2C (I)

2006/11/27 20:42

QLS2C. Freedom of thought and expression? (PROBE: Is that a right that should be guaranteed to everyone and never violated, a right that can be violated under certain circumstances, or not really a right at all?)

Guaranteed and never violated .................................................. 01

Can be violated under some circumstances ....................................02

Not really a right at all......................................................... 03

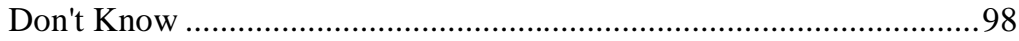

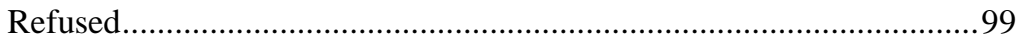

«QLS2C »

67:

QLS3 (I)

2006/11/27 20:42

QLS3. When you shop for various products for yourself or your home, how often do you look for products that are made in the USA? (READ CHOICES 1-5)

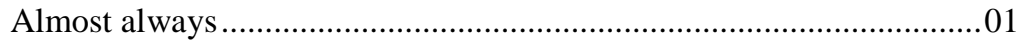

Most of the time ......................................................................... 02

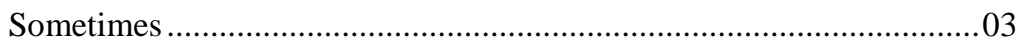

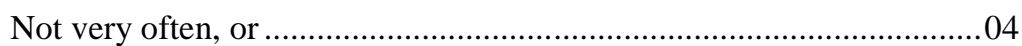

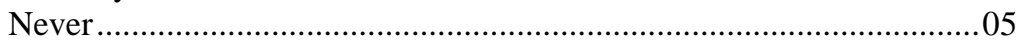

Don't Know ............................................................................... 98

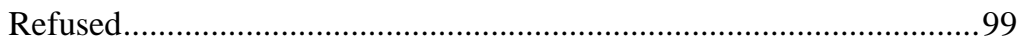

«QLS3 »

90:

2006/11/27 20:43

QLS5. Some products from developing countries carry a label saying "Fair Trade," that means the product was produced under fair and safe working conditions, and 
that the workers who produced it received a living wage. Have you ever seen this type of label?

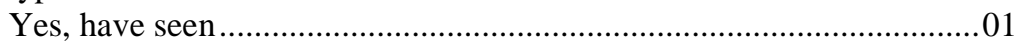

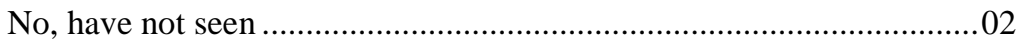

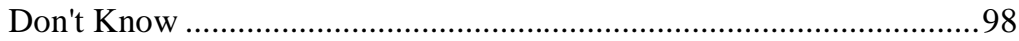

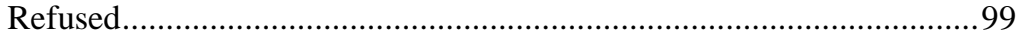

«QLS5 »

91:

QLS6 (I)

2006/11/27 20:43

QLS6. How often do you purchase coffee or coffee beans from a grocery store or supermarket? Regularly, sometimes, rarely, or never?

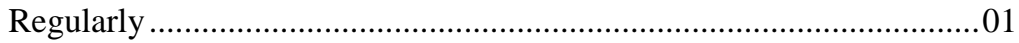

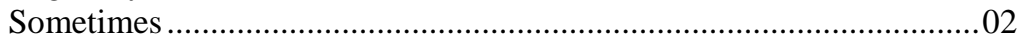

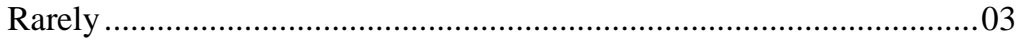

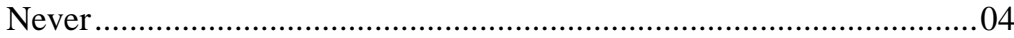

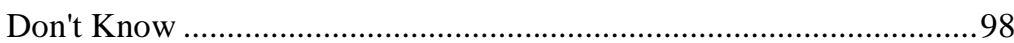

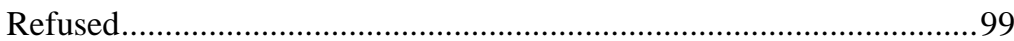

$\Rightarrow$ QPR 1

$\Rightarrow$ QPR 1

$\Rightarrow$ QPR1

«QLS6 »

$\Rightarrow$ QPR 1

\section{2:}

2006/11/27 20:43

QLS7. Coffee sold in supermarkets or grocery stores sometimes carries a "Fair

Trade" label. Have you ever purchased coffee with the "Fair Trade" label? (IF

YES: Do you purchase it regularly, sometimes, or have you purchased it a few times or less?)

=> QLS8
si QLS5>01

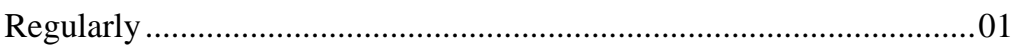

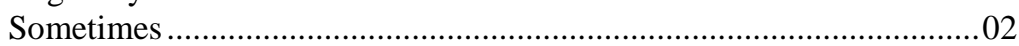

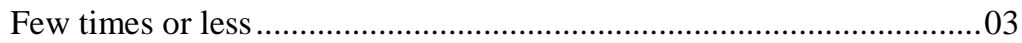

No, never purchased it.................................................................... 04

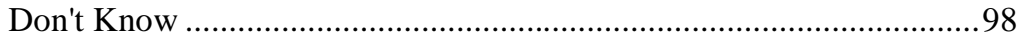

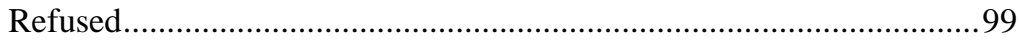

«QLS7 »

\section{3:}

2006/11/27 20:43

QLS8. When you buy coffee in the grocery store do you usually buy a generic or unknown brand, a common name brand like Folger's or Maxwell House, or a premium brand like Starbucks? (IF GIVEN NAME OTHER THAN THESE, PROBE: Is that a generic brand, a common brand, or a premium brand?)

Generic . .01

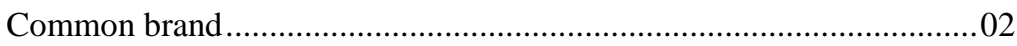

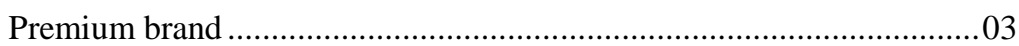

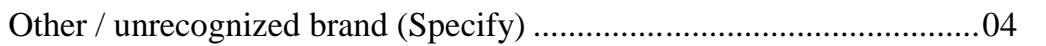

Don't Know ................................................................................98

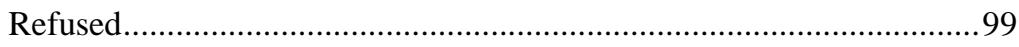

«QLS8 »

«O_QLS8 » 
94:

QLS9 (I)

2006/11/27 20:43

QLS9. Given what you currently pay for coffee, how much more per pound, if anything, would you be willing to pay for coffee that carries the 'Fair Trade'

label....fifty cents, one dollar, two dollars, more than two dollars, or nothing at all?

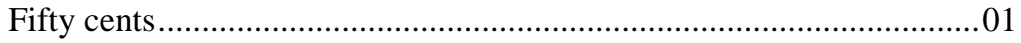

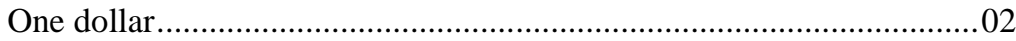

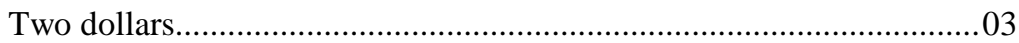

More than two dollars ............................................................

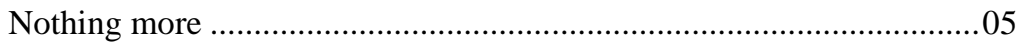

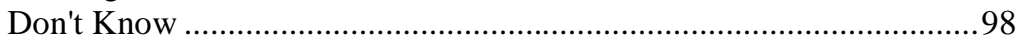

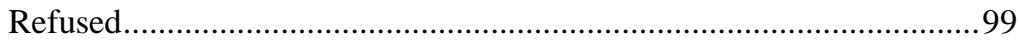

«QLS9 »

97:

QD1

2006/11/15 13:31

QD1. In what year were you born? (RECORD 4 DIGIT YEAR)

\$E 19001988

Don't Know ......

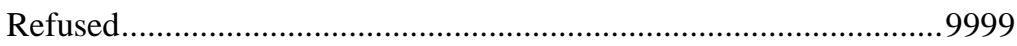

«QD1»

98:

QD2

2006/11/15 13:31

QD2. What is the highest grade of school or year of college you have completed

and gotten credit for?

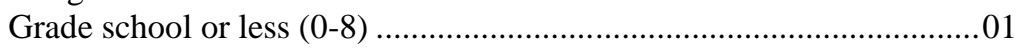

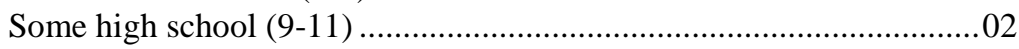

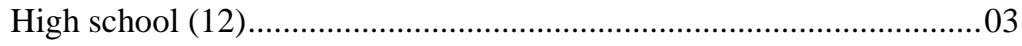

Some college (1-3 years) ..................................................................... 04

College graduate (4 years) .................................................................. 05

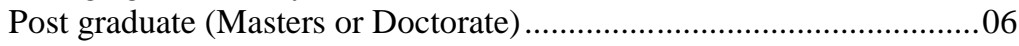

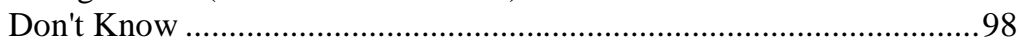

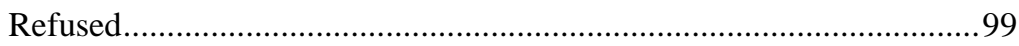

«QD2 »

99:

2006/11/15 13:33

QD3. Generally speaking, do you usually think of yourself as a Republican, a

Democrat, an independent, or what?

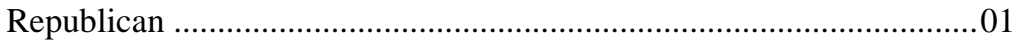

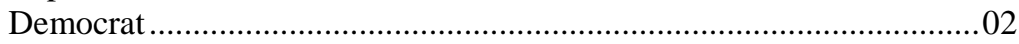

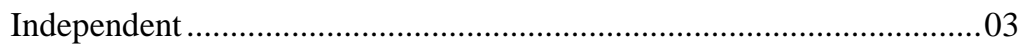

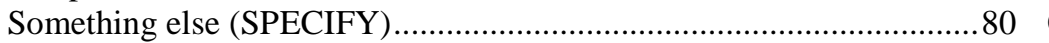

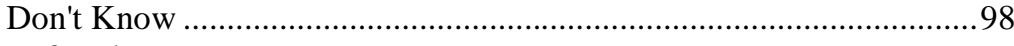

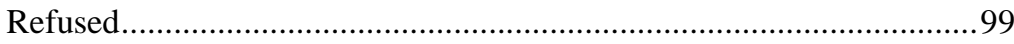

«QD3»

$\Rightarrow$ QD3B

$\mathrm{O} \quad \Rightarrow \mathrm{QD} 4$

$\Rightarrow$ QD4

$=>$ QD4

«O_QD3 » 
100:

2006/11/15 13:33

QD3A. Would you call yourself a strong or not very strong $\langle$ QD3 $>$ ?

Strong

$01 \quad \Rightarrow$ QD4

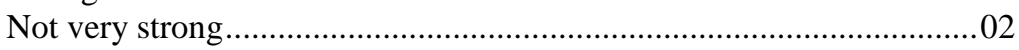

$\Rightarrow \mathrm{QD} 4$

Don't Know

$=>\mathrm{QD} 4$

Refused.

.98

$\Rightarrow \mathrm{QD} 4$

«QD3A »

101:

QD3B

2006/11/15 13:33

QD3B. Do you think of yourself as closer to the Republican Party or Democratic

Party or neither?

Republican Party ..................................................................... 01

Democratic Party ................................................................... 02

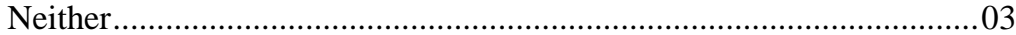

Don't Know .................................................................................. 98

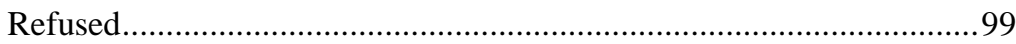

«QD3B »

102:

QD4

2006/11/15 13:34

QD4. What racial or ethnic group would you most identify yourself with? African

American, Asian, Hispanic, Native American, White, or some other group?

African American ................................................................................ 01

Asian ....................................................................................... 02

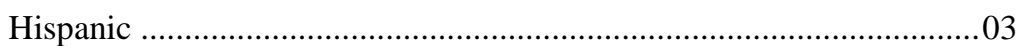

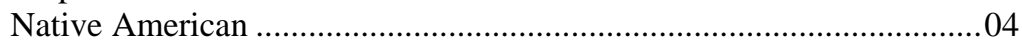

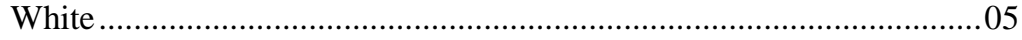

Some other group (SPECIFY) ................................................ 80 O

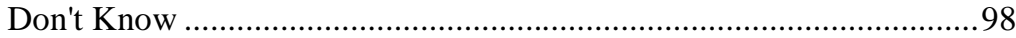

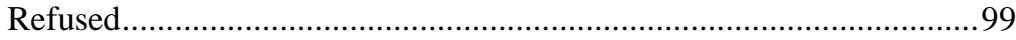

«QD4 » «O_QD4 »

\section{3:}

2006/11/15 13:38

QD5. When it comes to politics, do you usually think of yourself as very liberal, somewhat liberal, moderate, somewhat conservative, or very conservative?

Very Liberal 01

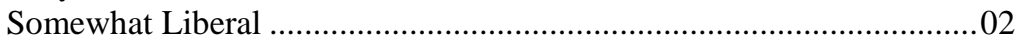

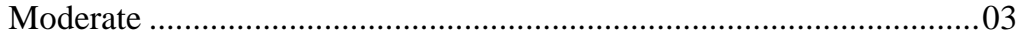

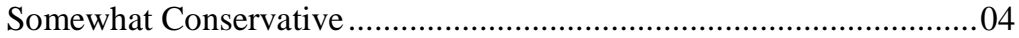

Very Conservative .............................................................................. 05

None of the above (vol.)................................................................... 97

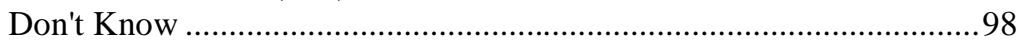

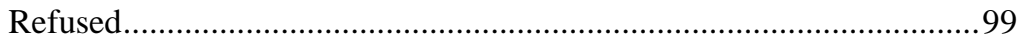

«QD5 » 
104:

2006/11/15 17:58

QD6. For classification purposes only, is the total yearly income of all the members of your family now living at home less than $\$ 50,000$ or is it $\$ 50,000$ or more?

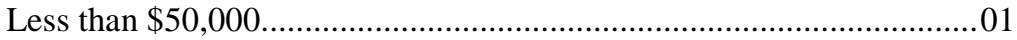

$\$ 50,000$ or more

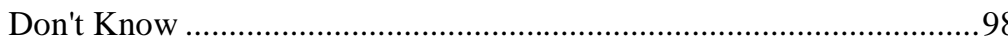

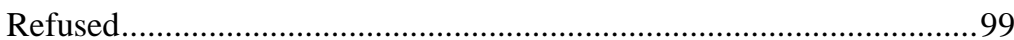

$\Rightarrow$ QD6B

$\Rightarrow$ QD7

«QD6 »

$=>$ QD7

\section{5:}

2006/11/15 13:37

QD6A. Is it... (READ CHOICES 1-4)

Under $\$ 25,000$

$\$ 25,000$ to less than $\$ 50,000$

$01 \quad \Rightarrow$ QD7

$\Rightarrow \mathrm{QD} 7$

Don't Know

$98 \quad \Rightarrow$ QD7

Refused 99

$\Rightarrow$ QD7

«QD6A »

\section{6:}

QD6B

2006/11/15 13:36

QD6B. Is it... (READ CHOICES 1-4)

$\$ 50,000$ to less than $\$ 75,000$ .01

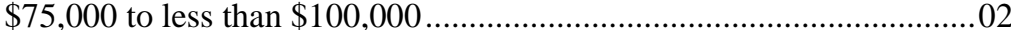

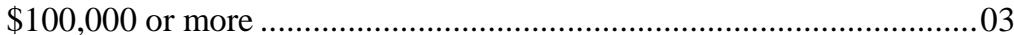

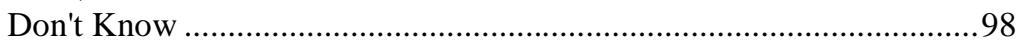

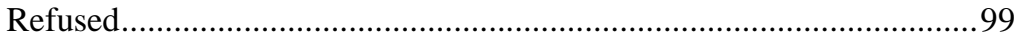

«QD6B »

108:

2006/11/15 13:34

QD8. How many adults live in this household who are 18 years old or older including yourself?

1

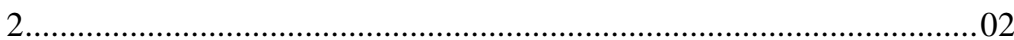

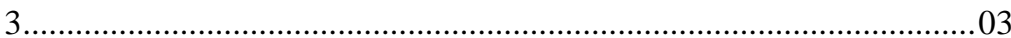

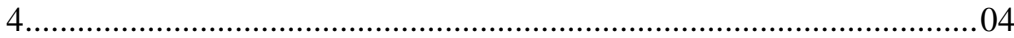

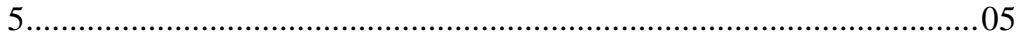

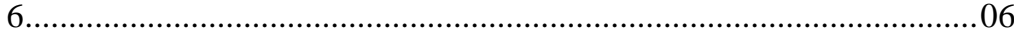

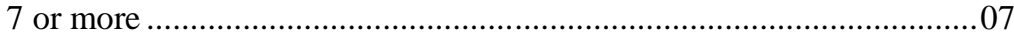

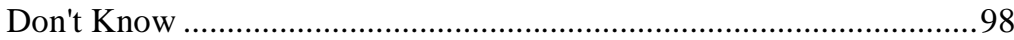

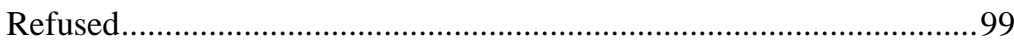

«QD8 »

109:

2006/11/15 13:34 
QD9. How many phone numbers do you have in your household that are connected to phones that can be answered by a person, excluding cell phones?

1 .

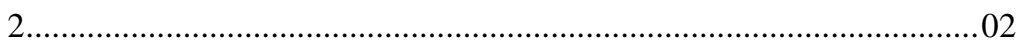

3

4

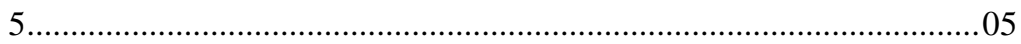

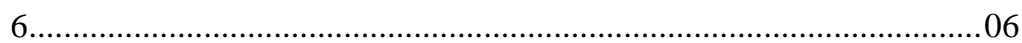

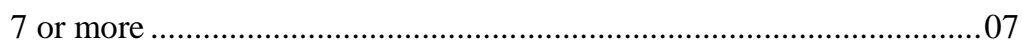

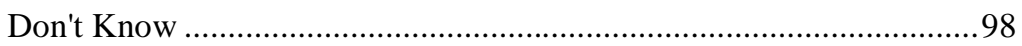

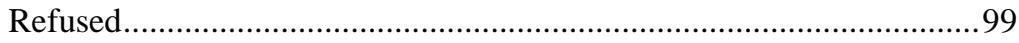

«QD9»

2006/11/15 13:34

QD10. (RECORD GENDER. DO NOT ASK)

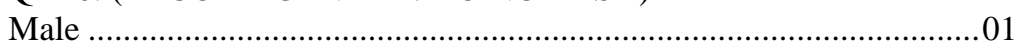

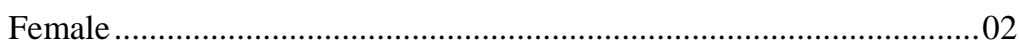

«D10» 


\section{Appendix B ${ }^{19}$ \\ Polling Data: Torture}

Public Agenda Confidence in US Foreign Policy Index Poll [February, 2007];

Conducted by Public Agenda Foundation, February 21-March 4, 2007

Pew Research Center for the People \& the Press 2007 Values Update Survey

[December, 2006]; Conducted by Princeton Survey Research Associates International, December 12-January 9, 2007

NBC News/Wall Street Journal Poll [September, 2006]; Conducted by Hart and McInturff Research Companies, September 30-October 2, 2006

Pew/AP Early October 2006 Turnout Poll [September, 2006]; Conducted by Princeton Survey Research Associates International, September 21-October 4, 2006

CBS News/New York Times Poll [September, 2006]; Conducted by CBS News/New York Times, September 15- September 19, 2006

Public Agenda Confidence in US Foreign Policy Index Poll [September, 2006];Conducted by Public Agenda Foundation, September 5-September 18, 2006

National Security Survey [September, 2006];Conducted by Benenson Strategy Group, September 13-September 14, 2006

Time/SRBI Poll [August, 2006]; Conducted by Schulman, Ronca, \& Bucuvalas, August 22-August 24, 2006

PIPA/BBC World Service Poll [June, 2006]; Conducted by Program On International Policy Attitudes, University of Maryland, June 8-June 27, 2006

Democracy Corps Poll [March, 2006]; Conducted by Greenberg Quinlan Rosner Research, March 16-March 20, 2006

Public Agenda Confidence in US Foreign Policy Index Poll [January, 2006];

Conducted by Public Agenda Foundation, January 10-January 22, 2006

ABC News/Washington Post Poll [December, 2005]; Conducted by ABC News/Washington Post, December 15-December 18, 2005

${ }^{19}$ Information on the surveys listed here was obtained from searches of the iPOLL Databank and other resources provided by the Roper Center for Public Opinion Research, University of Connecticut. All above data provided by Roper Center at University of Connecticut; Accessed June 19, 2007 and June 27, 2007. 
Associated Press/Ipsos-Public Affairs Poll [November, 2005]; Methodology:

Conducted by Ipsos-Public Affairs, November 15-November 28, 2005

Gallup/CNN/USA Today Poll [November, 2005]; Conducted by Gallup Organization, November 11-November 13, 2005

Princeton Survey Research Associates International/Newsweek Poll [November, 2005]; Conducted by Princeton Survey Research Associates International, November 10November 11, 2005

America's Place In The World Survey [October, 2005]; Survey by Pew Research Center, Council on Foreign Relations. Methodology: Conducted by Princeton Survey Research Associates International, October 12-October 24, 2005

Public Agenda Confidence in US Foreign Policy Index Poll [June, 2005]; Conducted by Public Agenda Foundation, June 1-June 13, 2005

Pew Research Center for the People \& the Press Political Typology Callback Poll [March, 2005]; Conducted by Princeton Survey Research Associates International, March 17-March 27, 2005

Gallup/CNN/USA Today Poll [January, 2005]; Survey by Cable News Network, USA Today. Methodology: Conducted by Gallup Organization, January 7-January 9, 2005

Pew Research Center for the People \& the Press/CFR Foreign Policy And Party Images Poll [July, 2004]; Methodology: Conducted by Princeton Survey Research Associates International, July 8-July 18, 2004

ABC News/Washington Post Poll [May, 2004]; Conducted by ABC News/Washington Post, May 20-May 23, 2004

ABC News Poll [September, 2003]; Conducted by ABC News, September 4-September 7,2003

Fox News/Opinion Dynamics Poll [March, 2003]; Conducted by Opinion Dynamics, March 11-March 12, 2003

Fox News/Opinion Dynamics Poll [March, 2002]; Conducted by Opinion Dynamics, March 12-March 13, 2002

Fox News/Opinion Dynamics Poll [December, 2002]; Conducted by Opinion Dynamics, December 3-December 4, 2002

TIPP/Investor's Business Daily/Christian Science Monitor Poll [November, 2001]; Conducted by TIPP--Techno Metrica Institute of Policy and Politics, November 7November 11, 2001 
Gallup/CNN/USA Today Poll [October, 2001]; Conducted by Gallup Organization, October 5-October 6, 2001

Millennium Survey [September, 1999]; Conducted by Taylor Nelson Sofres Intersearch, September 20-September 28, 1999 on behalf of Gallup International.

Parallel surveys were conducted in 49 other countries between August and October 1999.

Time/CNN/Yankelovich Partners Poll [January, 1993]; Conducted by Yankelovich Partners, January 13-January 14, 1993 


\section{Appendix $\mathbf{C}^{20}$ \\ Polling Data: Freedom of Thought Expression and Speech}

\section{Freedom of Thought}

Human Rights Survey [November, 1997]; Survey by Human Rights USA.

Methodology: Conducted by Peter D. Hart Research Associates, November 3-November 8, 1997

\section{Freedom of Expression}

ABC News Poll [May, 1999]; Methodology: Conducted by ABC News, May 5-May 9, 1999

Flag Survey [May, 1997]; Survey by Citizen's Flag Alliance. Methodology: Conducted by Wirthlin Worldwide, May 30-June 1, 1997

Flag Survey [March, 1996]; Survey by Citizen's Flag Alliance. Methodology: Conducted by Wirthlin Worldwide, March 25-March 28, 1996

Importance Of The Arts And Humanities To American Society [October, 1992]; Survey by National Cultural Alliance. Methodology: Conducted by Research \& Forecasts, October 14-October 29, 1992

Time/CNN/Yankelovich Clancy Shulman Poll [January, 1992]; Survey by Time, Cable News Network. Methodology: Conducted by Yankelovich Clancy Shulman on January 30,1992

NBC News/Wall Street Journal Poll [July, 1990]; Survey by NBC News, Wall Street Journal. Methodology: Conducted by Hart and Teeter Research Companies, July 6-July 10,1990

Federal Support For The Arts [March, 1990]; Survey by People for the American Way Action Fund. Methodology: Conducted by Research \& Forecasts, March 14-March 26, 1990

\section{Freedom of Speech}

Pew Research Center for the People \& the Press Values Update Survey [December, 2006]; Survey by Pew Research Center for the People \& the Press. Methodology:

Conducted by Princeton Survey Research Associates International, December 12-January 9, 2007

\footnotetext{
${ }^{20}$ Information on the surveys listed here was obtained from searches of the iPOLL Databank and other resources provided by the Roper Center for Public Opinion Research, University of Connecticut. All above data provided by Roper Center at University of Connecticut; Accessed June 19, 2007 and June 27, 2007.
} 
Gallup/USA Today Poll [June, 2006]; Survey by USA Today. Methodology: Conducted by Gallup Organization, June 23-June 25, 2006

Council for America's First Freedom Survey [July, 2005]; Survey by Council for America's First Freedom. Methodology: Conducted by Opinion Research Corporation, July 28-July 31, 2005

State Of The First Amendment Survey [May, 2005]; Survey by Freedom Forum, American Journalism Review. Methodology: Conducted by New England Survey Research Associates, May 13-May 23, 2005

State Of The First Amendment Survey 2004 [May, 2004]; Survey by Freedom Forum, American Journalism Review. Methodology: Conducted by Center For Survey Research \& Analysis, University of Connecticut, May 6-June 6, 2004

Pew Research Center for the People \& the Press Values Update Survey [July, 2003]; Survey by Pew Research Center for the People \& the Press. Methodology: Conducted by Princeton Survey Research Associates, July 14-August 5, 2003

State Of The First Amendment Survey 2003 [June, 2003]; Survey by The Freedom Forum, American Journalism Review. Methodology: Conducted by Center for Survey Research and Analysis, University of Connecticut, June 3-June 15, 2003

Pew Research Center for the People \& the Press Values Survey [July, 2002]; Survey by Pew Research Center for the People \& the Press. Methodology: Conducted by Princeton Survey Research Associates, July 2-August 8, 2002

State Of The First Amendment 2002 Survey [June, 2002]; Survey by The Freedom Forum. Methodology: Conducted by Center for Survey Research and Analysis, University of Connecticut, June 12-July 5, 2002

Civil Liberties Survey [October, 2001]; Survey by NPR, Harvard University, Henry J. Kaiser Family Foundation. Methodology: Conducted by ICR--International Communications Research, October 31-November 12, 2001

Conscience Clauses Survey [July, 2001]; Survey by American Civil Liberties Union. Methodology: Conducted by Belden Russonello \& Stewart, July 16-July 31, 2001

State of the First Amendment 2001 Survey [May, 2001]; Survey by The Freedom Forum. Methodology: Conducted by Center for Survey Research \& Analysis, University of Connecticut, May 16-June 6, 2001

State of the First Amendment Survey [April, 2000]; Survey by The Freedom Forum. Methodology: Conducted by Center for Survey Research and Analysis, University of Connecticut, April 3-April 26, 2000 
General Social Survey 2000 [February, 2000]; Methodology: Conducted by National Opinion Research Center, February 1-May 25, 2000

Pew Research Center for the People \& the Press Values Update Survey [September, 1999]; Survey by Pew Research Center for the People \& the Press. Methodology: Conducted by Princeton Survey Research Associates, September 28-October 10, 1999

Millennium Survey [September, 1999]; Methodology: Conducted by Taylor Nelson Sofres Intersearch, September 20-September 28, 1999

CBS News Poll [August, 1999]; Methodology: Conducted by CBS News, August 1August 3, 1999

NBC News/Wall Street Journal Poll [June, 1999]; Survey by NBC News, Wall Street Journal. Methodology: Conducted by Hart and Teeter Research Companies, June 16-June 19,1999

Americans Attitudes About the First Amendment Survey [February, 1999]; Survey by Freedom Forum. Methodology: Conducted by Center for Survey Research and Analysis, University of Connecticut, February 26-March 24, 1999

Washington Post/Kaiser Family Foundation/Harvard Americans on Values Followup Survey 1998 [August, 1998]; Survey by Washington Post, Henry J. Kaiser Family Foundation, Harvard University. Methodology: Conducted by Washington Post, August 10-August 27, 1998

Flag Survey [August, 1998]; Survey by Citizen's Flag Alliance. Methodology: Conducted by Gallup Organization during August, 1998

Pew Research Center for the People \& the Press Values Update Survey [November, 1997]; Survey by Pew Research Center for the People \& the Press. Methodology: Conducted by Princeton Survey Research Associates, November 5-November 17, 1997

Columbus Day Survey: Looking For America [July, 1997]; Survey by Wisconsin Public Television. Methodology: Conducted by Princeton Survey Research Associates, July 31-August 17, 1997

State Of The First Amendment Survey [July, 1997]; Survey by Freedom Forum. Methodology: Conducted by Center for Survey Research and Analysis, University of Connecticut, July 17-August 1, 1997

Flag Survey [May, 1997]; Survey by Citizen's Flag Alliance. Methodology: Conducted by Wirthlin Worldwide, May 30-June 1, 1997 


\section{Appendix $D^{21}$ \\ Polling Data: Child Labor, Fair Trade and Sweatshops}

\section{Child Labor}

Democracy Corps Poll [January, 2006]; Conducted by Greenberg Quinlan Rosner Research, January 22-January 25, 2006

Child Labor Survey [February, 2005]; Survey by National Consumers League, Child Labor Coalition. Methodology: Conducted by Opinion Research Corporation during February, 2005

Free Trade Survey [February, 2005]; Survey by Americans for Fair Trade. Methodology: Conducted by Ipsos-Public Affairs and Ayres, McHenry \& Associates, February 1-February 6, 2005

PSRA/Newsweek Poll [April, 2000]; Survey by Newsweek. Methodology: Conducted by Princeton Survey Research Associates, April 20-April 28, 2000

Connecting Women in the US and Global Issues Survey [January, 2000]; Survey by Aspen Institute. Methodology: Conducted by Belden Russonello \& Stewart, January 14February 5, 2000

Americans on Globalization Survey [October, 1999]; Methodology: Conducted by Program on International Policy Attitudes, University of Maryland, October 21-October 29, 1999

Consumers in the 21st Century Survey [April, 1999]; Survey by National Consumers League. Methodology: Conducted by Louis Harris \& Associates, April 22-May 3, 1999

Attitudes On Transatlantic Issues Survey [February, 1998]; Survey by German Marshall Fund of the US. Methodology: Conducted by Program on International Policy Attitudes, University of Maryland, February 13-April 20, 1998

Associated Press Poll [November, 1997]; Methodology: Conducted by Associated Press, November 12-November 16, 1997

AFL-CIO Communication Survey [January, 1997]; Survey by AFL-CIO. Methodology: Conducted by Peter D. Hart Research Associates, January 31-February 4, 1997

United Nations Survey [April, 1996]; Survey by United Nations Association of the USA. Methodology: Conducted by Wirthlin Group, April 2-April 4, 1996

\footnotetext{
${ }^{21}$ Information on the surveys listed here was obtained from searches of the iPOLL Databank and other resources provided by the Roper Center for Public Opinion Research, University of Connecticut. All above data provided by Roper Center at University of Connecticut; Accessed June 19, 2007 and June 27, 2007.
} 


\section{Fair Trade}

Pew Research Center for the People \& the Press America's Place In The World Survey [September, 1997]; Survey by Pew Research Center for the People \& the Press. Methodology: Conducted by Princeton Survey Research Associates, September 4, 1997September 11, 1997

New Democratic Electorate Survey [July, 1997]; Survey by Democratic Leadership Council. Methodology: Conducted by Penn, Schoen \& Berland Associates, July 23, 1997-July 27, 1997

\section{Sweatshops}

Americans on Globalization Survey [October, 1999]; Methodology: Conducted by Program on International Policy Attitudes, University of Maryland, October 21-October 29, 1999

\section{Sweatshops- Non-Roper References to Other Polling Data}

Dickson, Marsha A. "Utility of No Sweat Labels for Apparel Consumers: Profiling Label Users and Predicting Their Purchases," The Journal of Consumer Affairs 35, 1 (2001): 96-119.

Dickson, Marsha A. and Mary A. Littrell, "Consumers of Clothing from Alternative Trading Organizations: Societal Attitudes and Purchase Evaluative Criteria," Clothing and Textiles Research Journal 15 (1997): 20-33.

Dickson, Marsha A. and Mary A. Littrell, "Socially Responsible Behaviour: Values and Attitudes of the Alternative Trading Organisation Consumer," Journal of Fashion Marketing and Management 1 (October 1996): 50-69.

Elliott, Kimberly Ann and Richard B. Freeman, "White Hats or Don Quixotes? Human Rights Vigilantes in the Global Economy," Working Paper 8102, National Bureau of Economic Research (January 2001).

Marymount University. The Consumers and Sweatshops (Arlington, VA: Marymount University Center for Ethical Concerns, November 1999). Available online at: www.marymount.edu/news/garmentstudy/overview.html

Marymount University. Garment Workers Study, report available from Marymount University Center for Ethical Concerns (Arlington, VA: Marymount, 1996).

Marymount University. Garment Workers Study, report available from Marymount University Center for Ethical Concerns (Arlington, VA: Marymount, 1995). 
Roberts, James A. "Profiling Levels of Socially Responsible Consumer Behavior: A Cluster Analytic Approach and Its Implications for Marketing," Journal of Marketing 3 (Fall 1995): 97-117. 


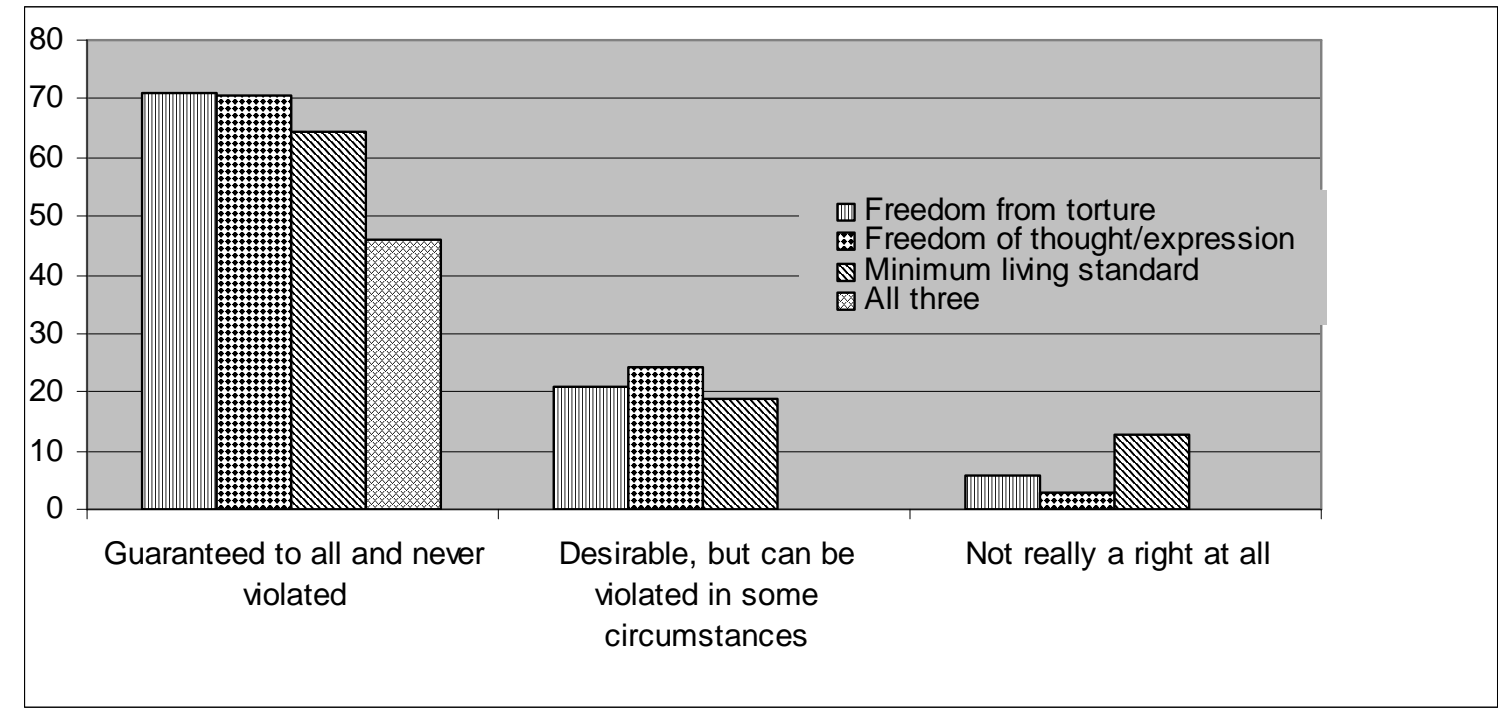

Figure 1: Beliefs about Human Rights 


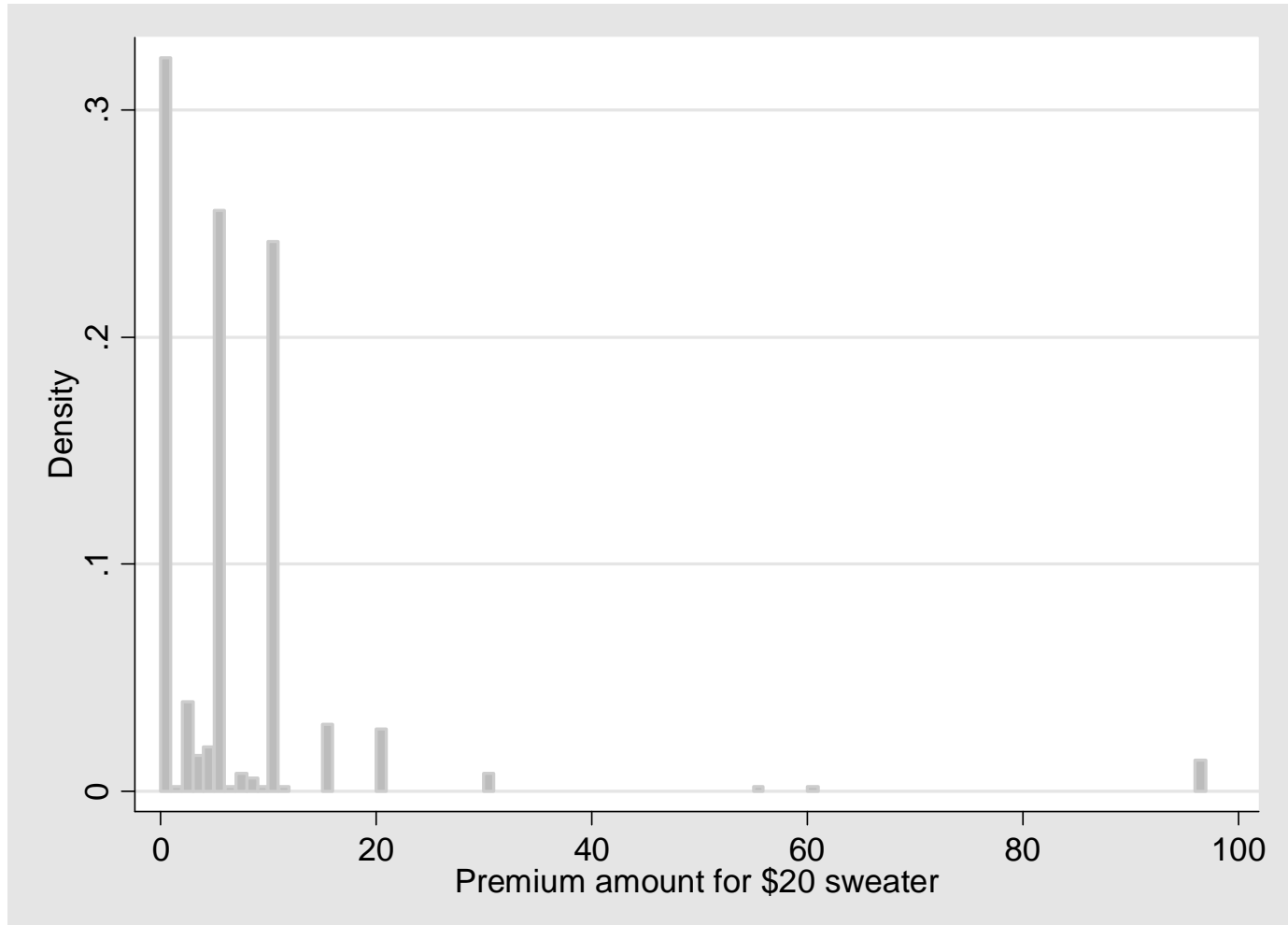

Figure 2: Willingness-to-pay more for Sweatshop-free sweater 


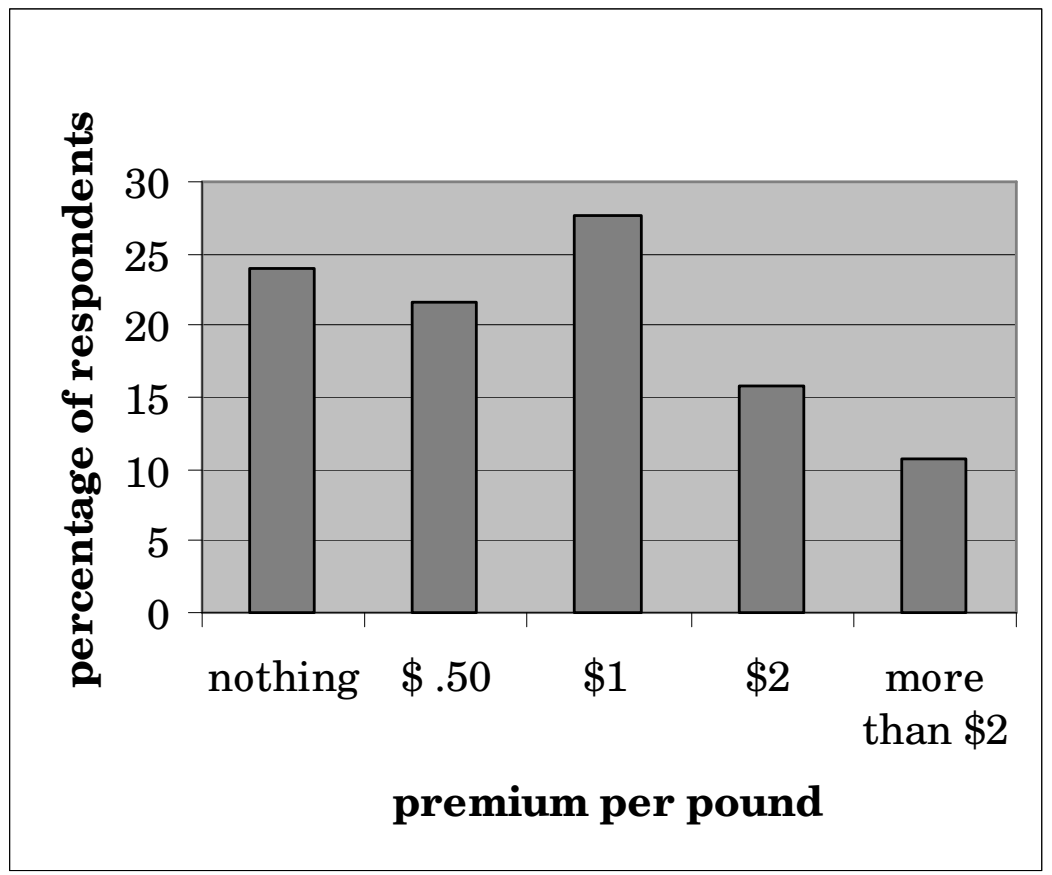

Figure 3: Willingness to pay more for Fair trade coffee 
Table 1: Support for guaranteed freedom from torture

\begin{tabular}{|c|c|c|c|c|}
\hline & Non-whites & Whites & & Result in multivariate analysis \\
\hline \multirow[t]{2}{*}{ Racial Group } & $80 \%$ & $67 \%$ & ** & \multirow[t]{2}{*}{ Non-whites 2.3 time more likely** } \\
\hline & Female & Male & & \\
\hline Gender & $78 \%$ & $63 \%$ & ** & \multirow[t]{3}{*}{ Females 2.2 time more likely**} \\
\hline & $<\$ 50 \mathrm{k} /$ year & $>\$ 50 \mathrm{k} /$ year & & \\
\hline Household income & $70 \%$ & $71 \%$ & $\mathrm{~ns}$ & \\
\hline
\end{tabular}

${ }^{* *}$ difference is statistically significant for $p<.05$ 
Table 2: Support unconditional minimum standard of living

\begin{tabular}{|c|c|c|c|c|}
\hline & Non-whites & Whites & & Result in multivariate analysis \\
\hline \multirow[t]{2}{*}{ Racial Group } & $70 \%$ & $62 \%$ & ** & Non-whites 1.9 times more likely * \\
\hline & Female & Male & & \\
\hline \multirow[b]{3}{*}{ Household income } & $65 \%$ & $64 \%$ & ns & ns \\
\hline & $<\$ 50 \mathrm{k} /$ year & $>\$ 50 \mathrm{k} /$ year & & \\
\hline & $\begin{array}{c}68 \% \\
\text { through } \\
\text { High School }\end{array}$ & $\begin{array}{c}63 \% \\
\text { more than } \\
\text { High School }\end{array}$ & ns & ns \\
\hline Education & $71 \%$ & $60 \%$ & ** & High School 2.2 times more likely** \\
\hline
\end{tabular}


Table 3: Support for unconditional right to freedom of thought and expression

\begin{tabular}{|c|c|c|c|c|}
\hline & Non-whites & Whites & & Result in multivariate analysis \\
\hline \multirow[t]{2}{*}{ Racial Group } & $64 \%$ & $74 \%$ & * & Non-whites .5 times as likely to support* \\
\hline & Female & Male & & \\
\hline \multirow[t]{2}{*}{ Gender } & $65 \%$ & $77 \%$ & ** & Females .4 time as likely to support ** \\
\hline & $<\$ 50 \mathrm{k} /$ year & $>\$ 50 \mathrm{k} /$ year & & \\
\hline \multirow[t]{2}{*}{ Household income } & $69 \%$ & $74 \%$ & ns & ns \\
\hline & $\begin{array}{c}\text { through } \\
\text { High School }\end{array}$ & $\begin{array}{c}\text { more than } \\
\text { High School }\end{array}$ & & \\
\hline Education & $69 \%$ & $71 \%$ & ns & ns \\
\hline
\end{tabular}

${ }^{*}$ marginally statistically significant, $\mathrm{p}<.10$

** statistically significant for $p<.05$ 
Table 4: Support for overall international human rights agenda

\begin{tabular}{|c|c|c|c|c|}
\hline & Non-whites & Whites & & Result in multivariate analysis \\
\hline \multirow[t]{2}{*}{ Racial Group } & $44 \%$ & $47 \%$ & ns & \\
\hline & Female & Male & & \\
\hline \multirow[t]{2}{*}{ Gender } & $51 \%$ & $40 \%$ & * & Females are 1.6 times more likely * \\
\hline & $<\$ 50 \mathrm{k} /$ year & $>\$ 50 \mathrm{k} /$ year & & \\
\hline \multirow[t]{2}{*}{ Household income } & $\begin{array}{c}45 \% \\
\text { through } \\
\text { High School }\end{array}$ & $\begin{array}{c}48 \% \\
\text { more than } \\
\text { High School }\end{array}$ & ns & ns \\
\hline & $\begin{array}{c}46 \% \\
\text { Democratic+ }\end{array}$ & $\begin{array}{c}45 \% \\
\text { Independent/ } \\
\text { Republican }\end{array}$ & ns & ns \\
\hline General Party Support & $54 \%$ & $39 \%$ & ** & Democrats are 1.9 times more likely** \\
\hline
\end{tabular}


Table 5: WTP more than $\$ 5$ for sweat-free sweater $(\max n=508)$

\begin{tabular}{|c|c|c|c|c|}
\hline Racial Group & Non-whites & Whites & & Result in multivariate analysis \\
\hline & $53 \%$ & $65 \%$ & * & Non-whites about .5 times as likely* \\
\hline \multirow[t]{2}{*}{ Gender } & Female & Male & & \\
\hline & $63 \%$ & $58 \%$ & ns & ns \\
\hline \multirow[t]{2}{*}{ Household income } & $<\$ 50 k /$ year & $>\$ 50 k /$ year & & \\
\hline & $\begin{array}{c}58 \% \\
\text { through } \\
\text { High School }\end{array}$ & $\begin{array}{c}67 \% \\
\text { more than } \\
\text { High School }\end{array}$ & * & over $\$ 50 \mathrm{~K} 1.9$ times more likely ** \\
\hline \multirow[t]{2}{*}{ General Party Support } & $\begin{array}{c}68 \% \\
\text { Democratic+ } \\
\end{array}$ & $\begin{array}{c}56 \% \\
\text { Independent/ } \\
\text { Republican }\end{array}$ & ** & High School 2.3 times more likely** \\
\hline & $61 \%$ & $61 \%$ & ns & ns \\
\hline \multirow[t]{2}{*}{ Age } & Under 40 & Over 40 & & \\
\hline & $67 \%$ & $58 \%$ & ns & ns \\
\hline \multirow[t]{2}{*}{ Int'I Human Rights Regime. } & Support & Do not Suppor & & \\
\hline & $65 \%$ & $58 \%$ & ns & ns \\
\hline \multirow[t]{2}{*}{ Right to standard of living } & Support & Do not Support & & \\
\hline & $69 \%$ & $58 \%$ & * & ns \\
\hline
\end{tabular}

+Democrat includes Independents who usually lean toward Democrats

* marginally statistically significant, $p<.10$

${ }^{* *}$ statistically significant for $p<.05$ 
Table 6: WTP more than $\$ 1$ more for Fair Trade Coffee ( $\max n=283)$

\begin{tabular}{|c|c|c|c|c|}
\hline Racial Group & Non-whites & Whites & & Result in multivariate analysis \\
\hline & $47 \%$ & $57 \%$ & ns & Non-whites .5 times as likely \\
\hline \multirow[t]{2}{*}{ Gender } & Female & Male & & \\
\hline & $53 \%$ & $56 \%$ & ns & ns \\
\hline \multirow[t]{2}{*}{ Household income } & $<\$ 50 \mathrm{k} /$ year & $>\$ 50 \mathrm{k} /$ year & & \\
\hline & $53 \%$ & $57 \%$ & ns & ns \\
\hline \multirow[t]{2}{*}{ Education } & High School & High School & & \\
\hline & $\begin{array}{c}55 \% \\
\text { Democratic+ }\end{array}$ & $\begin{array}{c}54 \% \\
\text { Independent/ } \\
\text { Republican }\end{array}$ & ns & ns \\
\hline General Party Support & $56 \%$ & $53 \%$ & ns & ns \\
\hline \multirow[t]{2}{*}{ Age } & Under 40 & Over 40 & & \\
\hline & $65 \%$ & $50 \%$ & ns & ns \\
\hline \multirow[t]{2}{*}{ Int'I Human Rights Regime } & Support & Do not Support & & \\
\hline & $58 \%$ & $50 \%$ & ns & ns \\
\hline \multirow[t]{2}{*}{ Right to standard of living } & Support & Do not Support & & \\
\hline & $59 \%$ & $44 \%$ & * & Supporter 1.9 times more likely* \\
\hline
\end{tabular}

+Democrat includes Independents who usually lean toward Democrats

${ }^{*}$ marginally statistically significant, $p<.10$

${ }^{* *}$ statistically significant for $p<.05$ 